\title{
GIS Multi-Criteria Analysis for Identifying and Mapping Forest Fire Hazard: Nevesinje, Bosnia and Herzegovina
}

\author{
Ljubomir GIGOVIĆ, Gordana JAKOVLJEVIĆ, Dragoljub SEKULOVIĆ, Miodrag REGODIĆ
}

\begin{abstract}
Fire risk management starts with an assessment of the most flammable places. In this paper, identification, classification and mapping of forest fire risk is completed with an aim of reducing the ratio and ecological damage caused by the fire. Suggested model is based on the combination of Geographical Information Systems and multi-criteria decision analysis using Analytic Hierarchy Process for mapping and assessment of forest fire risk in the area of Municipality Nevesinje, Bosnia and Herzegovina. The process was developed with an aid of 8 criteria grouped in four clusters. The weights are determined using AHP. Final map of forest fire risk is classified in 5 categories, from very low to very high risk, and indicates that $13.2 \%$ of Municipality area is in very high forest fire risk zone. The proposed method and the results of this study can be used for a policy of sustainable development at all levels of government.
\end{abstract}

Keywords: Bosnia and Herzegovina; forest fire; Geographic Information System (GIS); multi-criteria; Nevesinje; risk map

\section{INTRODUCTION}

Forest fires are considered to be natural disasters, which can endanger human life [1]. The causes of fire are most often directly related to human activities, such as negligence, carelessness, accident or arson on the forest areas. On the global scale, the fire destroys biodiversity and thus makes a great damage on ecosystem and intensifies the greenhouse effect [2, 3]. Fire releases large volumes of aerosols contaminants $\left(\mathrm{CO}, \mathrm{CO}_{2}, \mathrm{SO}_{2}, \mathrm{AM}\right.$, $\mathrm{PNE}$ and $\mathrm{OC}$ ), that significantly influence the Earth's atmospheric chemistry impacting on air quality and raising concern about risks to human health $[4,5,6]$. On local scale fire causes landslides, changes in the structure of soil and changes in vegetation $[7,8,9]$.

Recent research of JRC Technical Reports shows that, due to climate change increasing air temperature and decreasing of humidity, the area affected by forest fires in Europe could be doubled [10]. This fact rises concern and initiates serious analysis of this phenomenon and preventive modelling of forest fire risk. The aim is production of forest fire risk map. Forest fire risk zones are locations where a fire is highly likely to start, and from where it can easily spread to neighbourhood area. Identification of these zones helps us to discover areas with increased risk of forest fire occurrence and its development, which is the basis for emergency intervention planning. This creates favourable conditions for minimizing the number of fires and removing conditions for their formation.

Modern tools and technologies in combination with traditional knowledge could have great importance in prevention and forest fire control. Geographic information systems (GIS), in combination with other forms of technology such as remote sensing and computer modelling, are being used increasingly in all aspects of wildland fire management. Analysing scientific papers, in combination with GIS, several techniques were used for forest fire modelling, from logistic regression [9, 11], Analytic Hierarchy Process - AHP [12-18], AHP and Fuzzy analysis [18-23], neural network [24] to classification tree method [25].
Based on reference papers and experts opinion, Multicriteria Decision Making (MCDA) in combination with GIS technology is the most often used method for cartographical forest fire risk modelling.

Bosnia and Herzegovina $(\mathrm{B} \& \mathrm{H})$ is a country with a high risk of forest fires. On its territory in the period from 2007 to 2013 there was 177182 ha area burned to the ground, of which 115548 was forest [26, 27]. According to the European Forest Fire Information System's report, Bosnia and Herzegovina is on the high fourth place, right behind Algeria, Spain and Portugal, of the areas which were burned by fire [10]. In regional scale, the area of East Herzegovina is affected with the largest number of open fires (forest holdings Trebinje and Nevesinje).

In this study GIS-AHP MCDA model for forest fire risk mapping was presented in order to identify and classify suitability of zones on the occurrence of fire in the Nevesinje Municipality. Forest fire risk map will reduce risk of fires and improve activities of prevention [19].

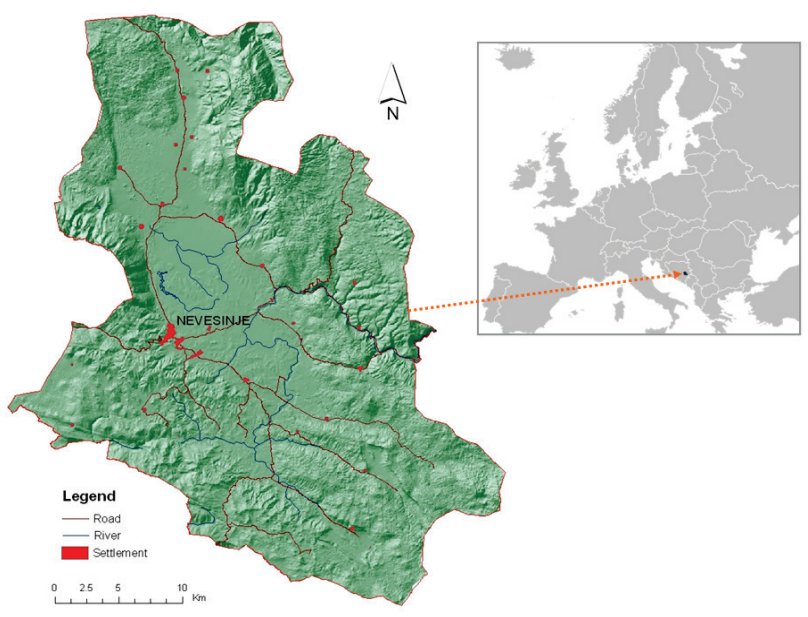

Figure 1 Map of Municipality of Nevesinje

\section{MATERIALS AND METHODS}

\subsection{Study Area}

Municipality Nevesinje is located in the south-east part of the Republic of Srpska $(\mathrm{B} \& \mathrm{H})$, east from Mostar and south from Sarajevo. Nevesinje lies between $17^{\circ} 58^{\prime}$ 
and $18^{\circ} 25^{\prime}$ longitude and $43^{\circ} 04^{\prime}$ and $43^{\circ} 29^{\prime}$ latitude. It belongs to the area of high Herzegovina with an average altitude of $860 \mathrm{~m}$ and it is characterized by the large karst field area of 17000 ha. Total area of the Municipality Nevesinje is $923.4 \mathrm{~km}^{2}$ (Fig. 1).

$63.34 \%$ of the Municipality territory is covered with forest and it represents a potential forest fire risk zone [27], especially in the period of July-August when there are the highest air temperatures and the lowest amounts of rain [28].

\subsection{Methods}

Methodological hierarchical model in this paper is based on the spatial structure of the MCDA. Spatial multicriteria decision analysis (SMCD) consists of procedures that involve the sharing of geographic data and preferences DO, and the manipulation of data and preferences according to specified decision rules [29]. The main advantage of the integration of GIS and MCDA is to have unique capabilities that complement each other. GIS has great possibilities for the manipulation, storage, management, analysis and visualization of geospatial data, while the MCDA provides a collection of procedures, techniques and algorithms for structuring decision problems, and designing, evaluating and prioritizing decision alternatives [30].

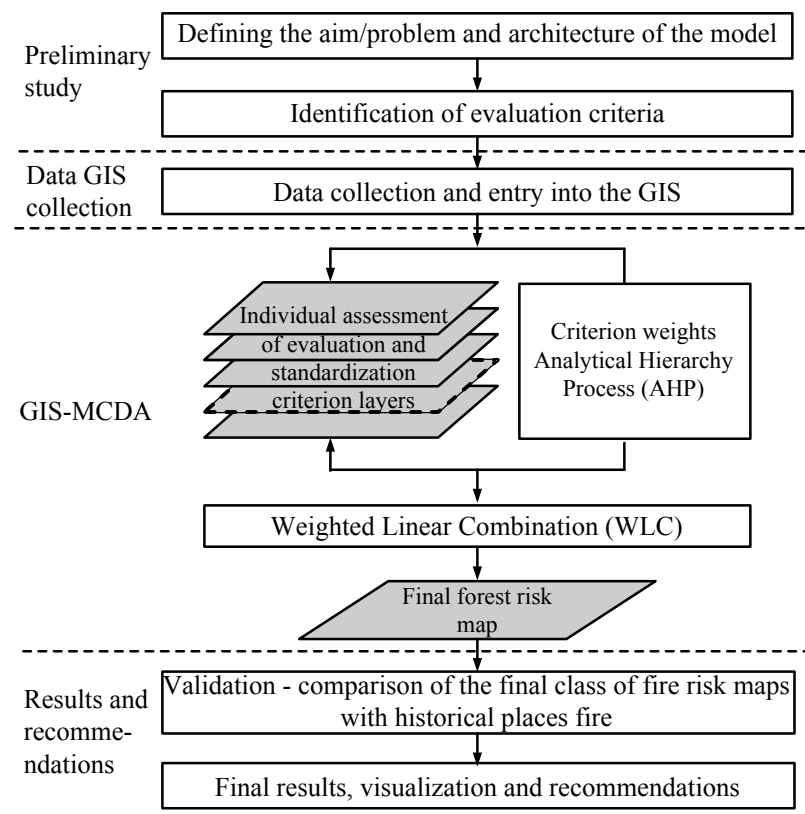

Figure 2 GIS-AHP MCDA of defining the critical zones for fires

Forest fire risk modelling has considered a wide range of hazard variables. The AHP method reduces complex decision in series of simple comparison and allows quantitative and qualitative comparison of criteria but there is not measurement of uncertainty in comparison and number of comparison significantly increases with the number of alternatives and criteria, which can be a big challenge [31]. From a methodological point of view, the proposed GIS AHP MCDA model defining fires crisis zones comprises the following steps (Fig. 2):

- Defining of aim/problem and defining of the architecture of model;
- Identification of criteria;

- Preparation of criterion layers for GIS;

- Multi-Criteria GIS evaluation (individual evaluation - standardization, determination of criteria weights (AHP) and aggregation criteria (WLC);

- GIS visualisation of final solution and recommendation.

Identification of criteria. In Bosnia and Herzegovina there is an accurate and reliable statistics on the occurrence of forest fires that could provide information about the locations of fire, therefore it is not possible to make an accurate location risk assessment at the level of smaller entities in order to make an assessment of their suitability to fire. Therefore, in order to reach the right conclusions, regardless of subjectivity in the evaluation, based on previous GIS MCDA study (Tab. 1) assessment was made of causative factors for spreading of fires and the possibility of their extinguishing. The study included six experts with experience in the field of risk management and environmental protection. During interviewing the experts collected data that are processed and aggregation of their opinions was made. Eight criteria grouped in four clusters, which are vital for starting of fire and forest fire risk assessment in the Municipality Nevesinje, are shown in Tab. 2.

GIS MCDA. This phase involves standardization, determination of weight and summary analysis of all the criteria, which are considered in the decision-making process. Application of weighted linear combination (WLC) requires that all data sets are standardized (reclassified) [30] in units that are comparable. There are a large number of approaches that can be used in order to make map attribute layers comparable, and some of them are described in Malczewski [32]. In accordance with the practice, the experts' experience and literature, the suitability of criteria, in this study, was performed using linear standardization on a score from 1 to 5 , where 5 is the highest risk and 1 is the lowest risk value of alternatives (a cell) for the ignition of the fire. Standardized criteria, with a defined class values are shown in Tab. 4. In this way, reclassified maps are transformed in GIS operational raster basis for the application of AHP multi-criteria process (Fig. 3.).

Determination of criteria weights AHP. In the process of solving real problems, the criteria do not have the same degree of significance, so it is necessary that decision maker define the significance of particular criteria by calculating the corresponding weight coefficient (weight) or weights of the criteria. Normalized weight of criteria is calculated by using multi-criteria technique in the form of AHP [31]. Methodologically speaking, the AHP is a multicriteria technique based on the comparison of elements in the same level of hierarchy relative with regard to the elements on a higher level. The goal is on the very top, under the criteria (sub-criteria, if any) and at the bottom of the alternatives. AHP first requires comparison of criteria and calculate their weight with regard to goal. Alternatives are then compared in pairs in respect to each criterion and in analogical process their relative weights are determined. 
Table 1 Criteria used in MCDA modeling for mapping forest fire risk

\begin{tabular}{|c|c|c|c|c|c|c|c|c|c|c|}
\hline Authors & 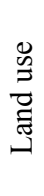 & 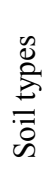 & 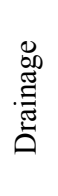 & 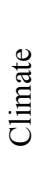 & 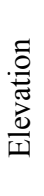 & $\frac{\ddot{\circ}}{\tilde{\sigma}}$ & 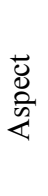 & 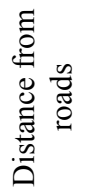 & 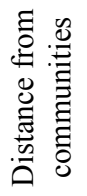 & 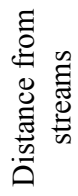 \\
\hline Hernandez-Leal et al.(2006) [9] & $*$ & & & & $*$ & $*$ & $*$ & $*$ & & \\
\hline Mahdav (2012) [12] & $*$ & & & $*$ & $*$ & $*$ & $*$ & & $*$ & \\
\hline Ariapour et al. (2014) [13] & $*$ & & & & $*$ & $*$ & $*$ & $*$ & $*$ & $*$ \\
\hline Chavan et al. (2012) [14] & $*$ & & $*$ & & & $*$ & $*$ & $*$ & $*$ & \\
\hline Setiawan et al. (2004) [16] & $*$ & & & & $*$ & $*$ & $*$ & $*$ & & \\
\hline Yakubu et al. (2013) [17] & $*$ & & & & $*$ & $*$ & $*$ & & & \\
\hline Vadrevu et al. (2009) [20] & & & & $*$ & $*$ & $*$ & $*$ & & & \\
\hline Garavand et al. (2015) [23] & & & & & $*$ & $*$ & $*$ & $*$ & $*$ & $*$ \\
\hline Adab et al. (2011) [33] & $*$ & & & & $*$ & $*$ & $*$ & $*$ & $*$ & \\
\hline Rajabi et al. (2013) [34] & $*$ & & & $*$ & & $*$ & & $*$ & $*$ & $*$ \\
\hline Kanabkaew et al. (2014) [ 35] & $*$ & $*$ & & & & & & $*$ & $*$ & $*$ \\
\hline
\end{tabular}

Table 2 Criteria description

\begin{tabular}{|c|c|c|}
\hline Klaster & Criteria & Criteria description \\
\hline 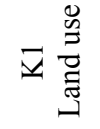 & $\mathrm{C} 1$ & $\begin{array}{l}\text { Vegetation. The main factor that affects the spread of a forest fire is the type and the characteristics of the } \\
\text { vegetation. The Vegetation is crucial for the fire spreading because it represents the total fuel available for the fire } \\
{[36] \text {. }}\end{array}$ \\
\hline \multirow{3}{*}{ 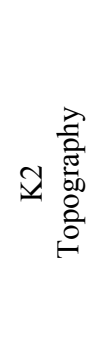 } & $\mathrm{C} 2$ & $\begin{array}{l}\text { Aspect. Generally, in the north hemisphere, south and southeast aspects are the most suitable for both, ignition and } \\
\text { spreading of fire [37], they receive more direct sunlight and because of that they have a higher temperature and a } \\
\text { minor humidity. }\end{array}$ \\
\hline & $\mathrm{C} 3$ & $\begin{array}{l}\text { Slope. The slope influences the fire behaviour. Steep slope can increase the rate of the fire spread [33]. Slope } \\
\text { affects speed and capability of firefighter and equipment movement and there for speed of fire extinguishing. } 10 \% \\
\text { increase of the slope can double the rate of the fire spreading. }\end{array}$ \\
\hline & $\mathrm{C} 4$ & $\begin{array}{l}\text { Elevation. Elevation is a crucial physiographic variable that is associated with wind behaviour and fire spreading. } \\
\text { Therefore it affects the structure of vegetation, total fuel available for fire, air humidity and temperature [38]. }\end{array}$ \\
\hline \multirow{2}{*}{$\underline{\underline{2}} \underset{\Xi}{\stackrel{\Xi}{\Xi}}$} & $\mathrm{C} 5$ & $\begin{array}{l}\text { Mean annual air temperature. Air temperature is one of the most important climate factors. Fires can occur at any } \\
\text { temperature, but their number depends on increasing of the temperature [39]. }\end{array}$ \\
\hline & C6 & $\begin{array}{l}\text { Mean annual precipitation. Precipitation is an important factor that influences suitability for ignition and fire } \\
\text { spreading. It appears in the form of air humidity, humidity of habitat and fuel. If fuel is dry, fire will spread faster } \\
{[20] \text {. }}\end{array}$ \\
\hline \multirow{2}{*}{ 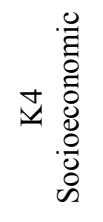 } & C7 & $\begin{array}{l}\text { Distance from roads. } 95 \% \text { of forest fires in the Mediterranean are caused by the human negligence. The roads are } \\
\text { a significant factor because their presence means human activity, therefore the forests near roads have a higher risk } \\
\text { of forest fires [27]. }\end{array}$ \\
\hline & C8 & $\begin{array}{l}\text { Distance from settlements. It was found that the man is the main cause of the fire, so it was logical that with } \\
\text { increasing of distance from human residence the number of fires would decrease }[32,40] \text {. }\end{array}$ \\
\hline
\end{tabular}

Table 3 Standardization criteria

\begin{tabular}{|c|c|c|c|c|c|}
\hline \multirow{3}{*}{ 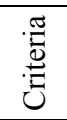 } & \multicolumn{5}{|c|}{ Intensity of importance } \\
\hline & 1 & 2 & 3 & 4 & 5 \\
\hline & very low & low & moderate & high & very high \\
\hline $\mathrm{C} 1 *$ & $(512)$ & $(112,332,333)$ & $(211,242,243)$ & $(222,231,321,324)$ & $(311,312,313)$ \\
\hline $\mathrm{C} 2$ & $\mathrm{~N}$ & $\mathrm{NE}, \mathrm{NW}$ & $\mathrm{E}, \mathrm{W}$ & Flat, SE & $\mathrm{S}, \mathrm{SW}$ \\
\hline C3 & $0-5^{\circ}$ & $5-15^{\circ}$ & $15-25^{\circ}$ & $25-35^{\circ}$ & $>35^{\circ}$ \\
\hline $\mathrm{C} 4$ & $>800 \mathrm{~m}$ & $600-800 \mathrm{~m}$ & $400-600 \mathrm{~m}$ & $200-400 \mathrm{~m}$ & $0-200 \mathrm{~m}$ \\
\hline $\mathrm{C5}$ & $<10^{\circ} \mathrm{C}$ & $10-15^{\circ} \mathrm{C}$ & $15-20^{\circ} \mathrm{C}$ & $20-25^{\circ} \mathrm{C}$ & $>25^{\circ} \mathrm{C}$ \\
\hline C6 & $>1750 \mathrm{~mm}$ & $1500-1750 \mathrm{~mm}$ & $1250-1500 \mathrm{~mm}$ & $1000-1250 \mathrm{~mm}$ & $<000 \mathrm{~mm}$ \\
\hline $\mathrm{C7}$ & $>1200 \mathrm{~m}$ & $900-1200 \mathrm{~m}$ & $600-900 \mathrm{~m}$ & $300-600 \mathrm{~m}$ & $0-300 \mathrm{~m}$ \\
\hline $\mathrm{C} 8$ & $>2000 \mathrm{~m}$ & $1500-2000 \mathrm{~m}$ & $1000-1500 \mathrm{~m}$ & $500-1000 \mathrm{~m}$ & $0-500 \mathrm{~m}$ \\
\hline
\end{tabular}

* Third level CORINE nomenclature 


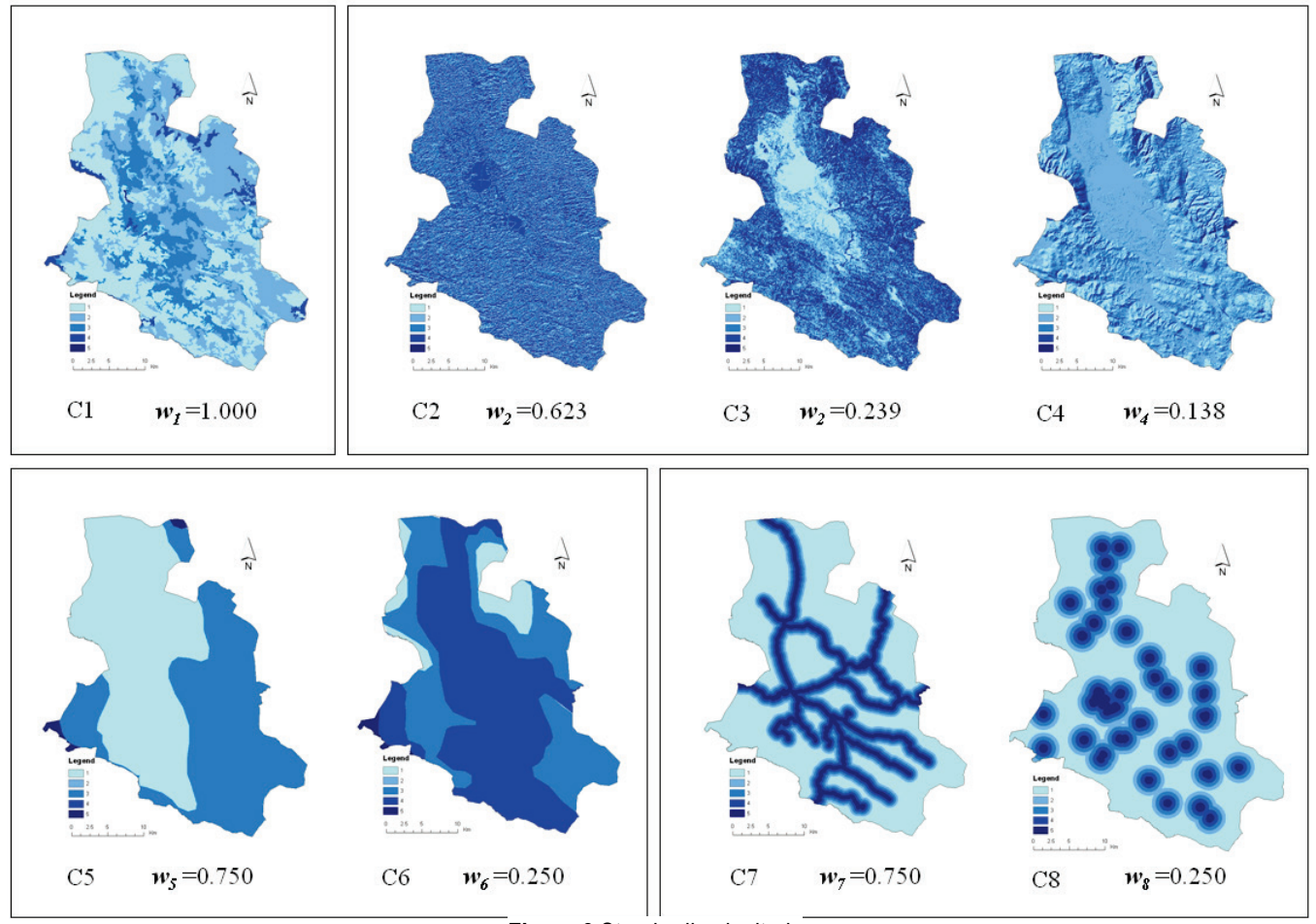

Figure 3 Standardized criteria

Observing the defined goal, for each pair of the criteria, the importance of one over the other are entered in the matrix of comparison. In this way, the amounts of cells along the matrix's diagonal is 1 (Tab. 4).

Table 4. Comparison matrix and weights to criteria

\begin{tabular}{|l|l|l|l|l|l|}
\hline Criteria & & $\mathrm{C} 2$ & $\mathrm{C} 3$ & $\mathrm{C} 4$ & $w_{i}$ \\
\hline Aspect (C2) & & 1 & 3 & 4 & 0,623 \\
\hline Slope (C3) & & $1 / 3$ & 1 & 2 & 0,239 \\
\hline Elevation (C4) & & $1 / 4$ & $1 / 2$ & 1 & 0,138 \\
\hline$\lambda_{\max }=3,026 \quad \mathrm{CI}=0,013 \quad \mathrm{CR}=0,022$ \\
\hline
\end{tabular}

\begin{tabular}{|l|l|l|l|}
\hline \multicolumn{1}{|c|}{ Criteria } & C5 & C6 & $w_{i}$ \\
\hline $\begin{array}{l}\text { Mean annual air temperature (1981- } \\
\text { 2010) (C5) }\end{array}$ & 1 & 3 & 0,750 \\
\hline $\begin{array}{l}\text { Mean annual precipitation (1981-2010) } \\
\text { (C6) }\end{array}$ & $1 / 3$ & 1 & 0,250 \\
\hline
\end{tabular}

\begin{tabular}{|l|l|l|c|}
\hline \multicolumn{1}{|c|}{ Criteria } & C7 & C8 & $w_{i}$ \\
\hline Distance from roads (C7) & 1 & 3 & 0,750 \\
\hline Distance of settlements (C8) & $1 / 3$ & 1 & 0,250 \\
\hline
\end{tabular}

After entering the value from Saaty's fundamental scale [32, 39] in Comparison matrix, weights of criteria $\left(w_{i}\right)$ are calculated. Comparison matrix at the cluster level is shown in Tab. 5.

Table 5 Comparison matrix and weights to clasters

\begin{tabular}{|l|l|l|l|l|c|}
\hline \multicolumn{1}{|c|}{ Klaster } & $\mathrm{K} 1$ & \multicolumn{1}{|c|}{ K2 } & $\mathrm{K} 3$ & \multicolumn{1}{|c|}{ K4 } & $w_{i}$ \\
\hline Land use (K1) & 1 & 3 & 4 & 2 & 0,450 \\
\hline Topography (K2) & $1 / 3$ & 1 & 2 & $1 / 3$ & 0,142 \\
\hline Climate (K3) & $1 / 4$ & $1 / 2$ & 1 & $1 / 4$ & 0,087 \\
\hline Socioeconomic (K4) & $1 / 2$ & 3 & 4 & 1 & 0,321 \\
\hline$\lambda_{\max }=4,108 \quad \mathrm{CI}=0,036 \quad \mathrm{CR}=0,040$ \\
\hline
\end{tabular}

\subsection{Data Collection and Input into a GIS}

Each of the defined criteria is represent in GIS in the form of spatially defined vectors, whose cells represent different alternatives. The used data and their sources are given in Tab. 6. All GIS processes (digitization, conversion, etc.) of inputting and spatial base of criteria building were accomplished using the integrated tools of ArcGIS 10.2. software of company ESRI. This area consists of 1477440 cells (resolution $25 \times 25 \mathrm{~m}$ ) representing alternative target by analysis.

Table 6 List of criteria their data and sources

\begin{tabular}{|l|l|l|}
\hline \multicolumn{1}{|c|}{ Criteria } & \multicolumn{1}{|c|}{ Data } & \multicolumn{1}{c|}{ Source } \\
\hline $\begin{array}{l}\text { Distance from } \\
\text { roads } \\
\text { Distance from } \\
\text { settlements }\end{array}$ & $\begin{array}{l}\text { Prostorni Plan } \\
\text { Republike } \\
\text { Srpske [41] }\end{array}$ & $\begin{array}{l}\text { Ministry of Spatial } \\
\text { Planning, Civil } \\
\text { Engineering and } \\
\text { Ecology }\end{array}$ \\
\hline Vegetation & $\begin{array}{l}\text { CORINE Land } \\
\text { Cover 2006 [42] }\end{array}$ & $\begin{array}{l}\text { European Environment } \\
\text { Agency }\end{array}$ \\
\hline $\begin{array}{l}\text { Aspect } \\
\text { Slope }\end{array}$ & $\begin{array}{l}\text { Digital Terrain } \\
\text { Elevation }\end{array}$ & $\begin{array}{l}\text { Republic administration } \\
\text { for geodetic } \\
\text { [43] }\end{array}$ \\
\hline $\begin{array}{l}\text { Mean annual air } \\
\text { temperature } \\
\text { (1981-2010) } \\
\text { Mean annual } \\
\text { precipitation } \\
\text { (1981-2010) }\end{array}$ & $\begin{array}{l}\text { Prostorni Plan } \\
\text { Republike } \\
\text { Srpske [41, 44] }\end{array}$ & $\begin{array}{l}\text { Ministry of Spatial } \\
\text { Planning, Civil } \\
\text { Engineering and } \\
\text { Ecology }\end{array}$ \\
\hline
\end{tabular}

\section{RESULTS AND DISCUSSION}

In the final realization is used Weighted Linear Combination (WLC) that is integrated into Spatial Analyst tools, according to the formula [16]:

$S=\Sigma w_{i} x_{i}$

where $S$ is the fire hazard rating, $w_{i}$ is normalized weight of factor $i$, and $x_{i}$ is the criterion score of factor $i$. As a result of multiplying weight criteria obtained as a result of 
AHP, with a cell's score of each criterion the final forest fire risk map is generated.

Based on defined criteria and clusters, final map is represented in the same score as criteria from 1 to 5 (Fig. 4). Larger values of cells score are characterized for location with high risk of fire ignition. On Fig. 4 areas that are the most critical when it comes to the spread of fire are represented with dark colours.

Study area, according the cell's value of forest fire is shown in Tab. 7.

Table 7 The areas of classes of final forest fire risk map

\begin{tabular}{|r|l|r|r|r|}
\hline \multicolumn{2}{|c}{ Classes } & $\begin{array}{r}\text { Area } \\
\left(\mathrm{km}^{2}\right)\end{array}$ & \multicolumn{1}{c|}{$\%$} & $\begin{array}{c}\text { Number of cells } \\
(25 \times 25)\end{array}$ \\
\hline 1 & Very low suitability & 47,2 & 5,1 & 75.505 \\
\hline 2 & Low suitability & 197,0 & 21,3 & 315.233 \\
\hline 3 & Moderate & 287,6 & 31,1 & 460.149 \\
\hline 4 & High & 270,2 & 29,3 & 432.357 \\
\hline 5 & Very high & 121,4 & 13,2 & 194.196 \\
\hline
\end{tabular}

Analysing the results, the total area of the most endangered area (value of cell 5) of forest fire in Nevesinje municipality is $121.4 \mathrm{~km}^{2}$, which is about $13.2 \%$ of its territory. Mainly, those areas are the parts of the municipality which are located near settlements on steep slopes and that are mostly covered by pastures and conifer forests.
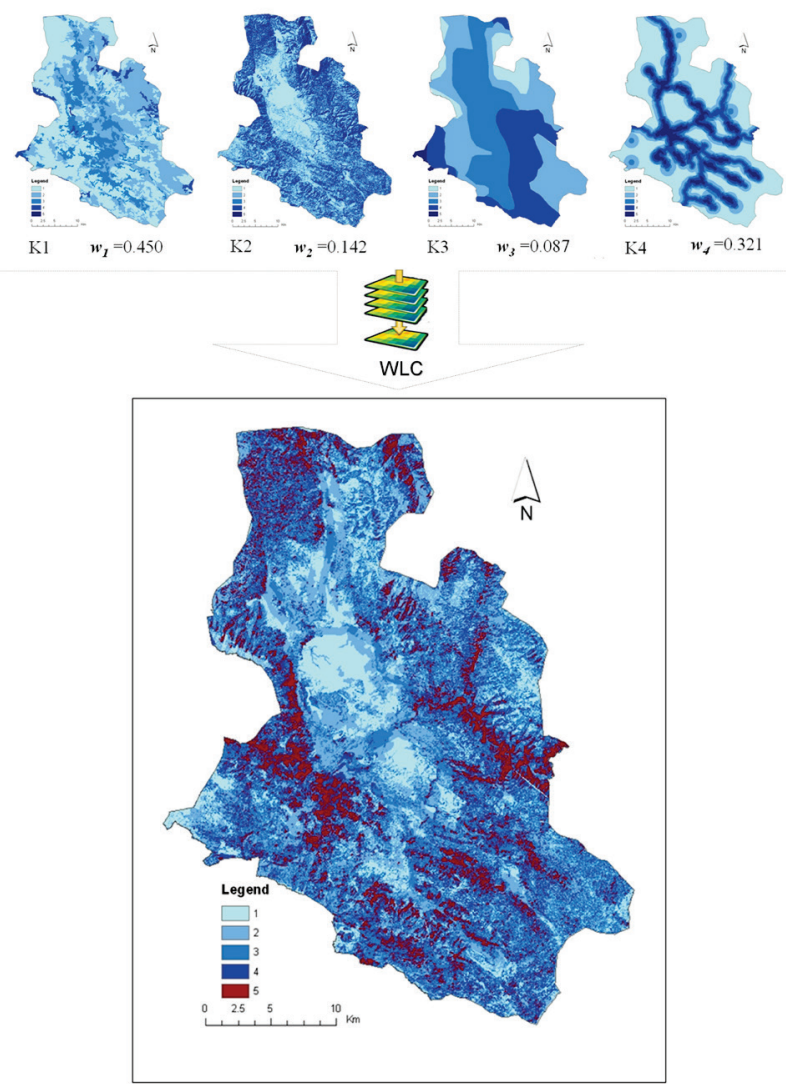

Figure 4 Aggregation of forest fire risk map, municipality of Nevesinje

\section{VALIDATION OF RESULTS}

Historical data are about forest fire was collected according to European Forest Fire Information systems report from 2010 to 2015 [10, 45, 46, 47, 48]. In 2012 and 2015 the study area was affected with 3 and 2 large forest fire respectively. Validation of proposed method was performed by establishing spatial relationship between historical data and forest fire map. For each historical data cell class of final forest fire risk is extracted by "Extract by Mask" algorithm (ArcGIS 10.2.). Results of analysis is show in Tab. 8

Table 8 Extracted level of forest fire risk for historical data cells

\begin{tabular}{|c|c|c|c|}
\hline Class & Very high & High & Moderate \\
\hline$\%$ & 82 & 13 & 5 \\
\hline
\end{tabular}

Analysing the results, $82 \%$ of cells of historical data has very high suitability, $13 \%$ has high and $5 \%$ moderate suitability.

\section{CONCLUSIONS}

The success of extinguishing forest fires and damage caused by them depends on the thoroughly studied and developed preventive measures. In this paper, combination of GIS and AHP MCDA method is used to determine forest fire risk zone in the municipality Nevesinje. Prediction of forest fires was carried out on 8 criteria grouped in four clusters (land use, topography, climate and socio-economic). The AHP multicriteria method is used to calculate a correspondent weight of criteria. Comparisons matrix are based on the experience of experts, literature and current practice. The final risk map is obtained in the WLC methods. Approximately $13.2 \%$ of the municipality Nevesinje area belongs to the zone of very high, $29.3 \%$ of the zone of high, $31.1 \%$ moderate zone, $21.3 \%$ of the low zone and $5.1 \%$ zone of very low risk of fire. For validation spatial relationship between forest fire risk map and historical data was performed. Results show that $82 \%$ of historical data cells are related to very high suitability so proposed model and map provide valuable information about the areas most likely to be affected by fire. It will be a useful tool in forest fire prevention and management in order to minimize forest fire hazard. Existing methodology can be applied to areas with similar geographical features.

Model shown in this paper can be improved by analysing new and modified criteria that are significant for this issues. In future, sensitivity analysis can be performed or AHP can be integrated with other MCDA tehniques (FAZZY AHP, TOPSIS, VIKOR ect.).

\section{REFERENCES}

[1] Zakon o šumam Republike Srpske, 66/03, 75/08 i 30/10. Službeni glasnik Republike Srpske.

[2] Jaiswal, R. K., Mukherjee, S., Raju, K. D., \& Saxena, R. (2002). Forest fire risk zone mapping from satellite imagery and GIS. International Journal of Applied Earth Observation and Geoinformation, 1(10). https://doi.org/10.1016/S0303-2434(02)00006-5

[3] Thonicke, K., Venevsky, S., Sitch, S., \& Cramer, W. (2001). The role of fire disturbance for global vegetation dynamics: coupling fire into a Dynamic Global Vegetation Model. Glob. Ecol. Biogeogr., 15(17), 661. https://doi.org/10.1046/j.1466-822X.2001.00175.x

[4] Andreae, O. \& Merlet, P. (2001). Emission of trace gases and aerosols from biomass burning. Global Biogeochemical Cycles, 15(11), 955. https://doi.org/10.1029/2000GB001382 
[5] Hardy, C. C., Ottmar, R. D., Peterson, J. L., Core, J. E., \& Seamon, P. (2001). Smoke management guide for prescribed and wild land fire. National Wildfire Coordination Group PMS 420-2, NFES 1279, 226.

[6] Sikva, J. C. D., Fiedler, N. C., Ribeiro, G. A., \& Silva Junior, M. C. D. (2003). Avaliação de brigadas de incêndios florestais em unidades de conservação. Revista Árvore, 27(6), 95.

[7] Goldammer, J. G. (1999). Forests on fire. Science, 284(1), 1782. https://doi.org/10.1126/science.284.5421.1782a

[8] Lwentile, L. B., Holden, Z. A., Smith, A. M. S., Falkowski, M. J., Hudak, A. T., \& Morgan, P. (2006). Remote sensing techniques to assess active fire characteristics and post-fire effects. International Journal of Wildland Fire, 15(26), 319. https://doi.org/10.1071/WF05097

[9] Hernandez-Leal, P. A., Arbelo, M., \& Gonzalez-Calvo, A. (2006). Fire Risk Assessment using Satellite Data. $A d v$ Space Res. 37(5), 741. https://doi.org/10.1016/j.asr.2004.12.053

[10] Forest Fire in Europe, Middle East and North Africa. $\mathrm{http} / / /$ forest.jrc.ec.europa.eu/media/cms_page_media/9/Fire Report2012_Final_2pdf(21.09.2015).

[11] Preisler, H. K., Brillinger, D. R., Burgan, R. E., \& Benoit, J. (2004). Probability based models for estimation of wildfire risk. Internationa Journal of Wildland Fire, 13(9), 133. https://doi.org/10.1071/WF02061

[12] Mahdavi, A., Fallah Shamsi, S. R., \& Nazar, R. (2012). Forests and rangellands' wildfire risk zoning using GIS and AHP techniques. Caspian J. Env. 10(9), 43.

[13] Ariapour, A. \& Mohamed Shariff, A. R. (2014). Rangeland Fire Risk Zonation using Remote Sensing and Geographical Information System Technologies in Boroujerd Rangelands, Lorestan Province, Iran. ECOPERSLA, 2(4).

[14] Chava, M. E., Das, K. K., \& Suryawanshi, R. S. (2012). Forest Fire risk zonation using Remote Sensing and GIS in Huynial watershed, Tehri Garhwal district, UA. International Journal of Basic and Applied Research, 2,

[15] Erden, T. \& Coskun, M. Z. (2010). Multi-criteria site selection for fire services: the interaction with analytic hierarchy process and geographic information systems. Nat. Hazards Earth Syst. Sci., 2127-2134. https://doi.org/10.5194/nhess-10-2127-2010

[16] Setiawan, I., Mahmud, A. R., Mansor, S., Mohamed Sharif, A. R., \& Nuruddin, A. A. (2004). GIS-grid-based and multi-criteria analzsis for identifying and mapping peat swamp forest fire hazard in Pahang, Malaysia. Disaster Prevention and Managment, 13(7), 379 https://doi.org/10.1108/09653560410568507

[17] Yakubu, I., Mireku-Gyimah, D., \& Duker, A. A. (2013). Multi-spatial Criteria Modelling of Fire Fisk and Hazard in the West Gonja Area of Ghana. Journal of Environmental and Earth Sciences, 267-277.

[18] Pourghasemi, H., Beheshtirad, M., \& Pradhan, B. (2014). A comparative assessment of prediction capabilities of modified analytical hierarchy process (M-AHP) and Mamdani fuzzy logic models using Netcad-GIS for forest fire susceptibility mapping. Gepomatics, Natural Hazards and Risk.

[19] Eskandari, S., Ghadikolaei, J. O., Jalilvand, H., \& Saradjian, M. R. (2013). Forest risk modeling and predoction in district three of Neka-Zalemroud forest, using Geographical Information System. Iranian Journal of Forest and Poplar Research, 21(14), 203.

[20] Vadrevu, K. P., Eaturu, A., \& Badarinath, K. V. S. (2010). Fire risk evaluation using multicriteria analysis-a case study. Environ Monit Assess, 166(16), 223. https://doi.org/10.1007/s10661-009-0997-3

[21] Atesoglu, A. (2014). Forest fire hazard identifying. Mapping using satellite imagery-geographic information system and analytic hierarchy process: Bartin, Turkey. J Environ prot ecol, 15(10), 715.
[22] Feizizadeh, B., Omrani, K., \& Aghdam, F. B. (2015). Fuzzy Analytical Hierarchical Process and Spatially Explicit Uncertainty Analysis Approach for Multiple Forest Fire Risk Mapping. Journal for Geographic Information Science, 1(8), 72. https://doi.org/10.1553/giscience2015s72

[23] Garavand, S., Yaralli, N., Borzouei, N., \& Sadeghi, H. (2015). Assessment of Fire Risk in Central Zagros Forests (Case Study: Chaharmahal Bakhtiari Province). Int. J. Rev. Life, 538-545.

[24] Vasilakos, C., Kalabokidis, K., Hatzopoulos, J., Kallos, G., \& Matsinos, Y. (2007). Integrating new methods and tools in fire danger rating. International Journal of Wildland Fire, 16(3), 306. https://doi.org/10.1071/WF05091

[25] Lozano, F. J., Suarez-Seoane, S., Kelly, M., \& Luis, E. (2008). A multi-scale approach for modeling fire occurrence probability using satellite data and classification trees: A case study in a mountainous Mediterranean region. Remote Sensing of Environment, 112(11), 708. https://doi.org/10.1016/j.rse.2007.06.006

[26] Regional Environmental Center for Central and Eastern Europe: Forest fires country study Bosnia and Herzegovina 2015. https://ec.europa.eu/jrc/en/news/2013-forest-fireshalved-in-the-eu, (21.09.2015).

[27] Studija Gašenje šumskih požara u Bosni i Hercegovini. Ministarstvo sigurnosti Bosne i Hercegovcine, http://msb.gov.ba/PDF/STUDIJA_O_GASENJU_POZAR A U BiH.pdf (06.02.2015.).

[28] Prostorni plan Opštine Nevesinje 2011-2031 Ministarstvo za prostorno uređenje, građevinarstvo i ekologiju Republike Srpske (2016).

[29] Malczewski，J. (1999). GIS and Multicriteria Decision Analysis, John Wiley and Sons, New York, 392.

[30] Eastman, J. R. (1999). IDRISI 32 Guide to GIS and image processing. Clark Labs, Clark University, Worcester, MA.

[31] Saaty, T. L. (1980). The Analytic Hierarchy Process. McGraw-Hill, New York, 287.

[32] Malczewski, J. (1999). GIS and Multicriteria Decision Analysis, John Wiley and Sons, New York, 392.

[33] Adab, H., Kanniah, K. D., \& Solaaimani, K. (2011). GISbased Probability Assessment of Fire Risk in Grassland and Forested Landscapes of Golastan Province, Iran. IPCBEE, 19.

[34] Rajabi, M., Alesheikh, A., Chehreghan, A., \& Gazmeh, H. (2013). An innovation Method for Forest Fire Risk Zoning Map Using Fuzzy Inference System and GIS. International Journal of Scientific \& Technology Research, 2.

[35] Kanabkaew, T., Rattanarat, J., \& Petcharoen, S. (2014). Development of a GIS-based forest fire risk map: case of Kuan Kreng swamp forest, Southern Thailand. SEE.

[36] Chuvieco, E. \& Congalton, R. G. (1989). Application of Remote Sensing and geographic Information Systems to Forest Fire Hazard Mapping. Remote sensing of Environment. https://doi.org/10.1016/0034-4257(89)90023-0

[37] Pyne, S. J., Andrewa, P. L., \& Laven, R. D. (1996). Introduction to Wildland Fire. John Wileys and Sons Inc., 221-227.

[38] Rathaur, S. (2006). Fire Risk Assessment for Tiger Preybase in Chilla Range andvicinity, Rajaji National Park using Remote Sensing and GIS. Thesis, Enschede, ITC, 1560.

[39] Netolicki, A., Blazevic, T., \& Antolovic, A. (2012). Visekriterijska analiza rizika od pozara u Splitskodalmatinskoj zupaniji. $\mathrm{KiG}, 17(11), 5$.

[40] Dong, X., Li-min, D., Guo-fan, S., Lei, T., \& Hui, W. (2005). Forest fire risk yone mapping grom satellite images and GIS for Baihe Forestry Burean, Jilin, China. Journal of Forestry Research, 16(3), 169-174. https://doi.org/10.1007/BF02856809 
[41] Prostorni plan Republike Srpske do 2015. godine, Banja Luka. Ministarstvo za prostorno uređenje, građevinarstvo i ekologiju Republike Srpske (2008).

[42] Corina Land Cover. (2006). European Environment Agency. http://www.eea.europa.eu/data-and-maps/data/ corine-land-cover-2006-raster-1.

[43] Orthofoto images (2009). Republic Administrarion for Geodetic and Property Affairs.

[44] Bajić, D. \& Trbić, G. (2016). Klimatski atlas Bosne i Hercegovine. Prirodno-matematički faklultet.

[45] Forest Fire in Europe, Middle East and North Africa 2014 //https://ec.europa.eu/jrc/en/publication/forest-fires-europemiddle-east-and-north-africa-2014. (23.02.2017)

[46] Forest Fire in Europe, Middle East and North Africa 2015. //https://ec.europa.eu/jrc/en/publication/forest-fires-europemiddle-east-and-north-africa-2015. (23.02.2017)

[47] Forest Fire in Europe, Middle East and North Africa 2013. //https://ec.europa.eu/jrc/en/publication/forest-fires-europemiddle-east-and-north-africa-2013. (23.02.2017)

[48] Forest Fire in Europe, Middle East and North Africa 2011. //https://ec.europa.eu/jrc/en/publication/forest-fires-europemiddle-east-and-north-africa-2011. (23.02.2017)

[49] Forest Fire in Europe, Middle East and North Africa 2010. //https://ec.europa.eu/jrc/en/publication/forest-fires-europemiddle-east-and-north-africa-2010. (23.02.2017)

\section{Contact information:}

Ljubomir GIGOVIĆ, Ph.D. Associate professor University of Defense, Department of Geography, Pavla Jurisica Sturma 33, 11000 Beograd, Serbia E-mail: gigoviclj@gmail.com

Gordana JAKOVLJEVIĆ, M.Sc. Assistant

University of Banja Luka,

Faculty of Architecture, Civil Engineering and Geodesy.

Vojvode Stepe Stepanovića 77/3

78000 Banja Luka, Republic of Srpska, Bosnia and Herzegovina

E-mail: gordana.jakovljevic@agfbl.org

Dragoljub SEKULOVIĆ, Ph.D. Full professor

University "Union - Nikola Tesla",

Faculty for Business Studies and Law in Belgrade

Jurija Gagarina 149a (TC Piramida), 11070, Belgrade, Serbia

E-mail: sekulovicdr@yahoo.co.uk

Miodrag REGODIĆ, Ph. D. Full professor

University of Banja Luka,

Faculty of Architecture, Civil Engineering and Geodesy,

Vojvode Stepe Stepanovića $77 / 3$

78000 Banja Luka, Republic of Srpska, Bosnia and Herzegovina

E-mail: mregodic62@gmail.com 